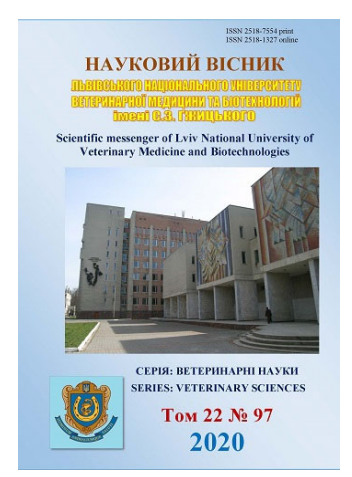

\section{Науковий вісник Дьвівського національного університету ветеринарної медицини та біотехнологій імені С.3. Гжицького. Серія: Ветеринарні науки}

\author{
Scientific Messenger of Lviv National University \\ of Veterinary Medicine and Biotechnologies. \\ Series: Veterinary sciences
}

doi: $10.32718 /$ nvlvet9730 https://nvlvet.com.ua/index.php/journal

UDC 619:616.99:595.421

\title{
Ixodid ticks in the Western Ukraine
}

\author{
V. A. Levytska, A. B. Mushynskyi
}

State Agrarian and Engineering University in Podilya, Kamianets-Podilskyi, Ukraine

Article info

Received 28.02.2020 Received in revised form 30.03.2020

Accepted 31.03.2020

State Agrarian and Engineering University in Podilya, Shevchenko St., 13, KamianetsPodilskyi, 32300, Ukraine. Tel.: +38-067-381-20-12 E-mail:Levytska28@gmail.com
Levytska, V. A., \& Mushynskyi, A. B. (2020). Ixodid ticks in the Western Ukraine. Scientific Messenger of Lviv National University of Veterinary Medicine and Biotechnologies. Series: Veterinary sciences, 22(97), 187-193. doi: 10.32718/nvlvet9730

During the 2018-2019 years, 2884 ticks were collected from five species of animals, including pets (dogs and cats), cattle (cows and horses) and wildlife (wild boar) in Khmelnytsky, Chernivtsi and Vinnytsia regions. Ixodid ticks were identified as: D. reticulatus (2370; $82.2 \%$ of all collected ticks), I. ricinus 510 $(17.7 \%)$ and 4 of I. hexagonus (0.1\%) from cats. Adult D. reticulatus (77\%) and I. ricinus (23\%) were detected in dogs. Ixodid ticks collected from horses were D. reticulatus (95\%) and I. ricinus (5\%), and from cows - D. reticulatus $(93 \%)$ and I. ricinus (7\%). I. ricinus was the predominant tick collected from cats (58\%). $100 \%$ of D. reticulatus was collected from wild boars. Most ticks were collected during the spring tick activity between March and May. However, D. reticulatus was found on animals every month, including the winter. D. reticulatus males accounted for the overwhelming majority of ticks collected in winter ( $68 \%$ for dogs, $84 \%$ for wild boars). In all other seasons D. reticulatus females prevailed - $66 \%$ in dogs, $77 \%$ in horses and $71 \%$ in cattle, in all areas. In addition, 4 females of I. hexagonus were removed from the cat in June. The average number of ticks per animal was about three ticks among dogs, two in cats, fourteen in cattle, seven in horses and seven in wild boars. Particularly high amount of D. reticulatus was recorded on cattle and horses in the spring. The relatively high amount of I. ricinus was observed in cats in the spring months. To evaluate the natural biocenoses of the three ticks species in the study areas, the ticks were collected using a flag in urban parks and rural areas. Two types of ticks were found in open areas. The density of adult D. reticulatus ticks in the open areas was relatively high, above 20 mites $/ 1000 \mathrm{~m}^{2}$ in most places. The density of adult ticks of I. ricinus was significantly lower in the typical habitat (forests), within 3 mites $/ 1000 \mathrm{~m}^{2}$, several times lower than the density of D. reticulatus in the typical habitat. Thus, in the western regions of Ukraine, two species of I. ricinus and D. reticulatus mites are widespread in natural biocenoses, as well as in farm and domestic animals, D. reticulatus is the dominant species. This type of tick is active throughout the year, so constant preventive treatment of animals is required to prevent infection with tick-borne diseases.

Key words: Dermacentor reticulatus, Ixodes ricinus, domestic animals, Western Ukraine.

\section{Видовий склад іксодових кліщів у Західному регіоні України}

\author{
В. А. Левицька, А. Б. Мушинський
}

Подільський державний аграрно-технічний університет, Кам'янець-Подільський, Україна

\footnotetext{
За період дослідження протягом 2018-2019 років було зібрано 2884 клішів від п'яти видів тварин, включаючи домашніх (собак та котів), сільськогосподарських (корів та коней) та диких тварин (дикий кабан) в Хмельницькій, Чернівецькій та Вінницькій областях. Виявлено три види кліщів: D. reticulatus (2370 особини; 82,2 \% усіх зібраних клішів), I. гісіпиs 510 особин (17,7\%) та 4 самки I. hexagonus (0,1\%) від котів. На собаках було виявлено дорослих D. reticulatus (77\%) та I. ricinus (23 \%). Фауна клімів у коней складалась з D. reticulatus (95\%) та I. ricinus (5\%), а у великої рогатої худоби - D. reticulatus (93 \%) та I. ricinus (7\%). I. ricinus був переважаючим видом кліщів, зібраним з котів (58 \%). 3 диких кабанів було зібрано 100 \% D. reticulatus. Hайбільше кліщів було зібрано у весняний пік активності кліщів у період з березня по травень. Однак D. reticulatиs був знайдений на тваринах кожного місяия, у тому числі в зимовий період. Самиі D. reticulatus становили переважну більшість кліщів, зібраних взимку (68\%
} 
для собак, $84 \%$ для диких кабанів). У всі інші сезони переважали самки D. reticulatus - $66 \%$ у собак, 77 \% у коней та $71 \%$ в великої рогатої худоби в усіх областях. Крім того, у червні в кота було видалено 4 самки I. hехаgопия. Середня інтенсивність ураження кліщами становила близько трьох кліщів серед собак, два - у котів, чотирнадчять - у великої рогатої худоби, сім - у коней $і$ сім - у диких кабанів. Особливо висока інтенсивність D. reticulatus була зафіксована на великій рогатій худобі та на конях навесні. Відносно висока інтенсивність ураження I. riсіпия виявлена на котах у весняні місяці. Для оцінки природніх біоценозів трьох видів клімів в досліджуваних областях кліщів збирали за допомогою прапора в міських парках та в приміських зонах. D. reticulatus та I. ricinus були виявлені на відкритих територіяx, I. hexagonus виявлено не було. Густота дорослих кліщів D. reticulatus на відкритих територіях була відносно високою, понад 20 кліщів/1000 м² у більшості місць. Густота дорослих кліщів I. гісіпия була значно нижчою у типовому середовищі існування (ліси), в межах 3 кліщів/1000 м², у кілька разів нижча, ніж щуільність D. гетісиаати у типовому середовищі існування. Отже, в західних областях України у природних біоценозах, а також серед сільськогосподарських та домашніх тварин широко поширені два види клішів I. ricinus та D. reticulatus, домінуючим видом є D. reticulatus. Даний вид кліщів $\epsilon$ активним протягом всього року, тому необхідними є постійні профілактичні обробки тварин для запобігання зараженню кліщовими захворюваннями.

Ключові слова: Dermacentor reticulatus, Ixоdes ricinus, свійські тварини, західна Украӥна.

\section{Вступ}

Кліщі родини Ixodidae налічують 713 видів, з яких 41 вид виявлено на території Свропи. В Україні описано 26 видів кліщів, це представники 6 родів: Ixodes, Dermacentor, Haemaphisalis, Boophilus, Rhipicephalus, Hyalomma (Iemchuk, 1960). Вони паразитують на домашніх і сільськогосподарських тваринах, серед них найпоширенішими видами кліщів є Ixodes ricinus та Dermacentor reticulatus (Roczeń-Karczmarz et al., 2018). Рід Dermacentor - переносники і резерванти збудників піроплазмідозів (бабезіозів) коней, свиней, собак, а також анаплазмозу великої рогатої худоби і збудників кліщового енцефаліту, кліщових рикетсіозів, туляремії, чуми та ін., патогенів, які мають велике значення в гуманній та ветеринарній медицині (Mierzejewska et al., 2013; Boulanger et al., 2019). D. reticulatus - головний переносник Babesia canis, збудника бабезіозу собак. Ця хвороба $\epsilon$ найпоширенішим клішовим захворюванням серед собак у всіх областях України, ендемічних для D. reticulatus. Іксодеси - переносники збудників бабезіозу великої рогатої худоби, анаплазмозу жуйних, а I. ricinus є ще переносником Borrelia burgdorferi s.l. (Boulanger et al., 2019).

I. ricinus та $D$. reticulatus відрізняються поширенням, ареалами, сезонною активністю та специфікою господаря (Nowak-Chmura \& Siuda, 2012). I. ricinus виявлено майже на всій території Україні, тимчасом як ареал D. reticulatus обмежений північною частиною країни. До типових біотопів I. ricinus належать листяні, хвойні та змішані ліси, пустирі, болота, пасовища та міські парки. Цей кліщ найактивніший з травня до початку жовтня і має дуже широке коло господарів: ящірки, багато видів птахів, дрібні, середні й великі ссавці та людина (Medlock et al., 2013). Для порівняння: вид D. reticulatus трапляється на відкритих територіях, таких як пасовища, луки, береги річок і озер, покриті високими травами та чагарниками, краї заболочених земель і лісові стежки (Bajer et al., 2014a). Вiн вперше з'являється ранньою весною, а після літньої діапаузи знову активний в кінці осені й навіть на початку зими, до перших снігопадів. Вважають, що основними господарями $є$ великі дикі та домашні ссавці, а також людина (Karbowiak, 2009).

Паразитування кліщів на домашніх та сільськогосподарських тваринах добре вивчене, однак проміжні живителі для певних видів кліщів ще вивчені мало. У разі незавершеного циклу живлення переривається життєвий цикл кліща. Таким чином, виявлення видів тварин, які підтримують завершення життєвих циклів конкретних видів кліщів, допомагає нам зрозуміти причини поширення цих кліщів та екологічну циркуляцію збудників, пов'язаних із відповідними видамипереносниками. В умовах швидкого розширення ареалу пасовищного кліща $D$. reticulatus та масштабів трансмісивних хвороб в багатьох європейських країнах останніми роками кілька авторів висловили припущення, що це пов'язано із розширенням та збільшенням кількості відповідних видів тварин, які можуть бути живителями (олені, лосі та кабани) (Karbowiak, 2009; Beugnet \& Chalvet-Monfray, 2013). Порівняно із загальною популяцією диких ссавців в Україні (приблизно 221 тис. копитних, 1,7 млн хутрових звірів), популяція сільськогосподарських та домашніх тварин значно більша. В Україні $є$ близько 3,3 млн великої рогатої худоби, 1,2 млн овець і кіз, 244 тис. коней, а також велика популяція собак (близько 6 млн) та котів (близько 7,5 млн) (Derzhavna sluzhba statystyky Ukrainy, 2019).

Таким чином, метою цього дослідження було визначити видовий склад кліщів серед сільськогосподарських та домашніх тварин в західних областях, ендемічних як для I. ricinus, так і для D. reticulatus; порівняти видовий склад кліщів у природніх біоценозах; оцінити сезонну активність кліщів.

\section{Матеріал і методи досліджень}

Протягом двох років (2018-2019) було зібрано 2884 іксодових кліщів (D. reticulatus та I. ricinus) від домашніх (кішка, собака), сільськогосподарських (великої рогатої худоби, коні) та диких (кабан) тварин в Хмельницькій, Чернівецькій та Вінницькій областях.

Кліщів збирали з собак (819 кліщів) та котів (376 кліщів), які потрапляли на прийом у ветеринарні лікарні міста Кам'янця-Подільського, Хмельницького, Чернівців, Вінниці.

Кліщів також знімали з великої рогатої худоби та коней, що утримувались на відкритих пасовищах, розташованих біля лісів. Кліщі з коней були зібрані в Хмельницькій та Чернівецькій областях, а $з$ великої рогатої худоби - у Хмельницькій та Вінницькій. 
Усього було знято 305 кліщів з коней та 1327 - 3 великої рогатої худоби. Середня кількість кліщів на одну тварину була розрахована, виходячи з кількості обстежених тварин.

Крім того, до цього дослідження було включено 57 кліщів, зібраних із восьми диких кабанів, знайдених взимку 2018-19 років.

Для визначення видового складу та ареалів поширення I. ricinus та D. reticulatus чисельність кліщів у навколишньому середовищі оцінювали для кожної місцевості окремо. Голодних кліщів збирали в тих самих районах, що і ситих кліщів від тварин. Кліщів збирали “на прапор” (1×1 м) протягом 2018 2019 років у міських парках та у сільській місцевості. Збори проводили двічі на день у пік активності між 911 год ранку та 16-18 год ввечері. Після визначення виду та статі за допомогою мікроскопії кількість була обчислена і виражена у кількості кліщів на 1000 м² $^{2}$ (Beklemishev, 1961).

Кліщів зберігали в 96 \% етанолі та досліджували в лабораторії паразитології на кафедрі інфекційних та інвазійних хвороб Подільського державного аграрнотехнічного університету. Вид, стать та стадію розвит- ку визначали у кожного кліща окремо (Filippova, 1977).

Первинні дані проаналізовані стандартними методами, що застосовуються в біологічній статистиці, за допомогою електронних таблиць Excel.

\section{Результати та їх обговорення}

\section{Результати досліджень}

Видовий склад кліщів серед сільськогосподарських та домашніх тварин в західних областях. За період дослідження було зібрано 2884 кліщі від п'яти видів тварин, включаючи домашніх тварин (собак та котів), худобу (корів та коней) та дику природу (дикий кабан). Виявлено три види кліщів: D. reticulatus 2370 особин (82,2 \% усіх зібраних кліщів), I. ricinus 510 особин $(17,7 \%)$ та 4 самки I. hexagonus $(0,1 \%)$ від котів (табл. 1, 2).

D. reticulatus був домінуючим видом кліщів, виявленим на чотирьох видах тварин, і становив 77, 93, 95 та 100 \% усіх кліщів у собак, великої рогатої худоби, коней та диких кабанів відповідно. На другому місці I. ricinus, що був домінуючим кліщем, зібраним 3 котів (58 \% всіх кліщів).

\section{Таблиця 1}

Видовий склад іксодових кліщів, виявлений на домашніх тваринах в західних областях України

\begin{tabular}{|c|c|c|c|c|c|c|c|c|}
\hline \multirow{2}{*}{ Область } & \multirow{2}{*}{ Вид тварин } & \multicolumn{2}{|c|}{ Період } & \multicolumn{5}{|c|}{ Кількість кліщів } \\
\hline & & Сезон & DRF & DRM & DR всього & IRF & IRM & IR всього \\
\hline \multirow{10}{*}{ Хмельницька } & \multirow{5}{*}{ Собаки } & Весна & 79 & 32 & 111 & 23 & 5 & 28 \\
\hline & & Літо & 27 & 4 & 31 & 19 & 3 & 22 \\
\hline & & Осінь & 32 & 13 & 45 & 6 & 1 & 7 \\
\hline & & Зима & 5 & 9 & 14 & 0 & 0 & 0 \\
\hline & & Всього & 147 & 54 & 201 & 48 & 9 & 57 \\
\hline & \multirow{5}{*}{ Коти } & Весна & 9 & 2 & 11 & 45 & 11 & 56 \\
\hline & & Літо & 12 & 4 & 16 & 19 & 2 & 21 \\
\hline & & Осінь & 7 & 1 & 8 & 3 & 0 & 3 \\
\hline & & Зима & 0 & 0 & 0 & 1 & 0 & 1 \\
\hline & & Всього & 28 & 7 & 35 & 68 & 13 & 81 \\
\hline \multirow{10}{*}{ Чернівецька } & \multirow{5}{*}{ Собаки } & Весна & 69 & 41 & 110 & 32 & 7 & 39 \\
\hline & & Літо & 3 & 5 & 8 & 4 & 0 & 4 \\
\hline & & Осінь & 17 & 8 & 25 & 6 & 3 & 9 \\
\hline & & Зима & 1 & 5 & 6 & 0 & 0 & 0 \\
\hline & & Всього & 94 & 55 & 149 & 42 & 10 & 52 \\
\hline & \multirow{5}{*}{ Коти } & Весна & 23 & 15 & 38 & 18 & 21 & 39 \\
\hline & & Літо & 2 & 1 & 3 & 13 & 8 & 21 \\
\hline & & Осінь & 16 & 9 & 25 & 5 & 4 & 9 \\
\hline & & Зима & 0 & 2 & 2 & 0 & 3 & 3 \\
\hline & & Всього & 41 & 27 & 68 & 36 & 36 & 72 \\
\hline \multirow{10}{*}{ Вінницька } & \multirow{5}{*}{ Собаки } & Весна & 108 & 54 & 162 & 29 & 23 & 52 \\
\hline & & Літо & 21 & 11 & 32 & 6 & 8 & 14 \\
\hline & & Осінь & 42 & 37 & 79 & 12 & 3 & 15 \\
\hline & & Зима & 2 & 4 & 6 & 0 & 0 & 0 \\
\hline & & Всього & 173 & 106 & 279 & 47 & 34 & 81 \\
\hline & \multirow{5}{*}{ Коти } & Весна & 17 & 10 & 27 & 34 & 18 & 52 \\
\hline & & Літо & 0 & 3 & 3 & 2 & 5 & 7 \\
\hline & & Осінь & 11 & 7 & 18 & 6 & 0 & 6 \\
\hline & & Зима & 2 & 1 & 3 & 0 & 0 & 0 \\
\hline & & Всього & 30 & 21 & 51 & 42 & 23 & 65 \\
\hline
\end{tabular}

Примітка: DR - Dermacentor reticulatus; IR - Ixodes ricinus; F - самка; $\mathrm{M}$ - самець

* - до таблиці не включено 4 самки I. Hexagonus, виявлених у котів влітку 
На собаках було виявлено дорослих D. reticulatus (77\%) та I. ricinus (23\%). Фауна кліщів у коней складалась з D. reticulatus (95\%) та I. ricinus (5\%), у великої рогатої худоби - D. reticulatus $(93 \%)$ та I. ricinus (7\%), у котів - D. reticulatus $(41 \%)$, I. ricinus $(58 \%)$ та I. hexagonus $(1 \%)$.

Сезонна активність кліщів. Існували значні відмінності у складі кліщів між сезонами. Найбільше кліщів було зібрано у весняний пік активності кліщів у період з березня по травень. Однак D. reticulatus знаходили на тваринах кожного місяця, у тому числі в зимовий період. Пасовищний кліщ був домінуючим видом серед собак і коней навесні та восени і був єдиним видом, виявленим на собаках та диких кабанах у зимові місяці.

Взимку 2018-2019 років з диких кабанів було зібрано 57 кліщів, і всі вони були визначені як D. reticulatus. Прохолодна погода тривала 3 кінця грудня до кінця березня, спостерігався сніг і температура нижче ніж $0{ }^{\circ} \mathrm{C}$ протягом більшої частини цього періоду, але була досить довга і тепла осінь, що призвело до появи D. reticulatus в собак у цей період.

Середня інтенсивність ураження кліщами становила близько трьох кліщів серед собак, два - у котів, чотирнадцять - у великої рогатої худоби, сім - у коней і сім - у диких кабанів. Особливо висока інтенсивність D. reticulatus була зафіксована на великій рогатій худобі та конях навесні. Відносно висока інтенсивність ураження I. ricinus виявлена на котах у весняні місяці.

Самці D. reticulatus становили переважну більшість кліщів, зібраних взимку (68 \% для собак, 84 \% для диких кабанів). У всі інші сезони самки D. reticulatus переважали серед усіх кліщів, зібраних у собак (66 \%), коней $(77 \%)$ та великої рогатої худоби (71\%) в усіх областях. Крім того, у червні в кота було виявлено лише 4 самки I. hexagonus, самців не виявили жодного.

Порівняння видового складу кліщів у природніх біоценозах. Для оцінки природніх біоценозів трьох видів кліщів в досліджуваних областях кліщів збирали за допомогою прапора в міських парках та в приміських зонах. D. reticulatus та I. ricinus були виявлені на відкритих територіях, I. hexagonus виявлено не було. Густота дорослих кліщів D. reticulatus на відкритих територіях була відносно високою, понад 20 кліщів/1000 м² у більшості місць. Густота дорослих кліщів I. ricinus була значно нижчою у типовому середовищі існування (ліси), в межах 3 кліщів/1000 м², у кілька разів нижча, ніж щільність D. reticulatus у типовому середовищі існування.

При аналізі пропорційного співвідношення виявлення кліщів D. reticulatus та I. ricinus у тварин навесні, в час пікової активності для обох видів кліщів, виявилось подібне співвідношення. Співвідношення кліщів D. reticulatus до I. ricinus становило в середньому 4,5:1. Однак лише у котів ця пропорція була зворотна - 1:1,4 на користь I. ricinus.

\section{Обговорення}

Метою дослідження було визначити видовий склад іксодових кліщів серед домашніх та сільськогосподарських тварин, а також у природних біоценозах у трьох областях, ендемічних для I. ricinus та D. reticulatus. Встановлено, що D. reticulatus був домінуючим видом серед великої рогатої худоби, коней, собак та диких кабанів, за винятком котів, у яких переважали кліщі I. ricinus. Найбільшу кількість кліщів було зібрано навесні, а також восени. Навесні чисельність кліщів D. reticulatus була значно вищою за I. ricinus у типових місцях їхнього існування, що становить більший ризик зараження.

\section{Таблиця 2}

Видовий склад іксодових кліщів виявлений на сільськогосподарських тваринах в західних областях України

\begin{tabular}{|c|c|c|c|c|c|c|c|c|}
\hline \multirow{2}{*}{$\begin{array}{c}\text { Вид } \\
\text { тварин }\end{array}$} & \multirow{2}{*}{ Область } & \multicolumn{2}{|c|}{ Період } & \multicolumn{5}{|c|}{ Кількість кліщів } \\
\hline & & Сезон & DRF & DRM & DR всього & IRF & IRM & IR всього \\
\hline \multirow{10}{*}{$\begin{array}{c}\text { Велика } \\
\text { рогата } \\
\text { худоба } \\
(98)\end{array}$} & \multirow{5}{*}{$\begin{array}{c}\text { Хмельницька } \\
\text { (56) }\end{array}$} & Весна & 311 & 81 & 392 & 17 & 9 & 26 \\
\hline & & Літо & 14 & 10 & 24 & 0 & 1 & 1 \\
\hline & & Осінь & 78 & 39 & 117 & 9 & 5 & 14 \\
\hline & & Зима & 0 & 0 & 0 & 0 & 0 & 0 \\
\hline & & Всього & 403 & 130 & 533 & 26 & 15 & 41 \\
\hline & \multirow{5}{*}{$\begin{array}{c}\text { Вінницька } \\
\text { (42) }\end{array}$} & Весна & 296 & 166 & 462 & 18 & 11 & 30 \\
\hline & & Літо & 16 & 18 & 34 & 2 & 0 & 2 \\
\hline & & Осінь & 163 & 48 & 211 & 11 & 4 & 15 \\
\hline & & Зима & 0 & 0 & 0 & 0 & 0 & 0 \\
\hline & & Всього & 475 & 232 & 707 & 31 & 15 & 46 \\
\hline \multirow{10}{*}{ Коні (41) } & \multirow{5}{*}{$\begin{array}{c}\text { Хмельницьк а } \\
\text { (24) }\end{array}$} & Весна & 54 & 18 & 72 & 3 & 0 & 3 \\
\hline & & Літо & 9 & 0 & 9 & 2 & 0 & 2 \\
\hline & & Осінь & 38 & 5 & 43 & 4 & 0 & 4 \\
\hline & & Зима & 0 & 0 & 0 & 0 & 0 & 0 \\
\hline & & Всього & 101 & 23 & 124 & 9 & 0 & 9 \\
\hline & \multirow{5}{*}{$\begin{array}{c}\text { Чернівецька } \\
\text { (17) }\end{array}$} & Весна & 74 & 28 & 102 & 3 & 2 & 5 \\
\hline & & Літо & 2 & 0 & 2 & 0 & 0 & 0 \\
\hline & & Осінь & 45 & 16 & 61 & 1 & 0 & 0 \\
\hline & & Зима & 0 & 1 & 1 & 0 & 0 & 0 \\
\hline & & Всього & 121 & 45 & 166 & 4 & 2 & 6 \\
\hline
\end{tabular}

Примітка: DR - Dermacentor reticulatus; IR - Ixodes ricinus; F - самка; M - самець 
Фауна кліщів у тваринництві та серед домашніх тварин залежить головним чином від географічного положення, оскільки різні види кліщів мешкають на різних континентах, а географічний ареал для різних видів кліщів визначається наявністю певних видів тварин. У нашому дослідженні вид кліщів D. reticulatus складав 82,2 \% усіх кліщів, зібраних 3 тварин, і це збігається з даними, одержаними у Європі (Caminade et al., 2019).

В попередніх дослідженнях в Україні встановлено, що D. reticulatus становив $63 \%$ (Hamel et al., 2013), у Білорусії - 61,6 \% (Reye et al., 2013). Україна, а також сусідні країни, населені східною популяцією цього вида кліща, i, очевидно, ризик нападу даного виду у цьому регіоні високий (Karbowiak, 2009; Karbowiak, 2014). В інших регіонах центральної Свропи також виявлено кліщів D. reticulatus у собак: у Німеччині $45 \%$ кліщів (Beck et al., 2014); в Угорщині - $49 \%$ кліщів (Földvári \& Farkas, 2005). У дослідженні в Австрії D. reticulatus становив $15 \%$ усіх кліщів, але був домінуючим на початку весни та пізньої осені (Duscher et al., 2013). У всіх країнах, де D. reticulatus є важливою складовою фауни кліщів у собак, потенційним $є$ підвищений ризик зараження собак бабезіозом, оскільки цей вид кліщів є основним переносником $B$. Canis (Karbowiak, 2009; Zygner et al., 2009). Пасовищний кліщ досить рідко трапляється у Великобританії та Бельгії (0,6-0,8 \%), але останнім часом був виявлений як постійний компонент фауни кліщів серед собак цих країн (Smith et al., 2011; Claerebout et al., 2013). Цікаво, що на півдні Польщі D. reticulatus не виявлено серед 236 кліщів, зібраних з собак, а виявлено лише I. ricinus та I. hexagonus (Kilar, 2011).

У нашому дослідженні європейський лісовий кліщ I. ricinus становив лише $17,7 \%$ кліщів, це досить низький відсоток порівняно 3 попередніми даними 3 України (36 \%) та з країн Свропи (Hamel et al., 2013). Відсоток I. ricinus становив 43 та $46 \%$ відповідно до останніх досліджень в Угорщині та Німеччині (Földvári \& Farkas, 2005; Beck et al., 2014). Найвищий відсоток цього виду кліщів був виявлений серед собак з Великобританії 52-72 \% (Ogden et al., 2000; Smith et al., 2011), 76 \% - у Бельгії (Claerebout et al., 2013), 76 \% - в Австрії (Duscher et al., 2013), а також 89 \% на півдні Польщі (Kilar, 2011).

Однак у Свропі спостерігається значно більша чисельність кліщів виду $D$. reticulatus порівняно 3 I. ricinus на відкритих ділянках в природних умовах існування, які найчастіше використовуються для вигулу собак та худоби (Welc-Falęciak et al., 2014). Тому в подальшому при розширенні ареалу пасовищного кліща ризик зараження трансмісивними хворобами зросте в кілька разів. Нині в деяких країнах Свропи вже виявлено показники збільшення зараження собак кліщовими хворобами, які спостерігаються внаслідок розширення ареалу D. Reticulatus (Bajer et al., 2014b).

I. hexagonus виявляли досить рідко в Україні і лише від їжаків (Kolonin, 2006). Однак, 22-39 \% кліщів, знятих з собак у Великобританії, а також 10,6 \% у Польщі, належали до даного виду (Ogden et al., 2000;
Smith et al., 2011; Kilar, 2011). Наші дані збігаються 3 даними, отриманими з Угорщини та Австрії, де 0,10,4 \% кліщів становили I. hexagonus (Földvári \& Farkas, 2005; Duscher et al., 2013).

Встановлено, що велика рогата худоба, коні, собаки та дикі кабани є живителями для D. reticulatus, але переваги до жодного виду тварин не виявлено. Переважання виду D. reticulatus над I. ricinus може бути пов'язано зі значно меншим життєвим циклом D. reticulatus порівняно 3 I. ricinus (1-річний проти 2-річного життєвого циклу) (Zahler \& Gothe, 1995). Цікаво, що хоча I. ricinus переважав на кішках і вважається, що цей вид господарів не $є$ характерним живителем для D. reticulatus, було виявлено даний вид кліщів на котах, тому котів можна вважати господарями для D. reticulatus. Велика рогата худоби та собаки є переважними господарями для кліщів D. reticulatus, що підтверджується виявленням значної кількості ситих самок на цих видах тварин. На тваринах, яких регулярно обробляли акарицидами, виявляли значно меншу кількість кліщів або мертвих особин.

За нашими даними кліщі виду D. reticulatus були виявлені на собаках протягом усього року, включаючи зимовий період, а також були зібрані в незначній кількості протягом зими від котів, коней та досить багато - від диких кабанів. Наявність D. reticulatus на тваринах та в навколишньому середовищі взимку раніше було зафіксовано іншими авторами, на відміну від I. ricinus, який у зимові місяці практично відсутній. С повідомлення, що кліщів виду D. reticulatus виявляли взимку в Німеччині (Dautel et al., 2008) та Польщі (Buczek et al., 2014). Інші види живителів, на яких були виявлені кліщі взимку, включають лося та оленя (Izdebska, 2001). Взимку було зібрано кліщів обох статей, але самців було більше, як і у нашому дослідженні. Самці D. reticulatus становили понад $68 \%$ усіх кліщів, зібраних протягом зими. Подібні дані наводять й інші дослідники (Izdebska, 2001; Karbowiak, 2009; Buczek et al., 2014).

Встановлено, що D. reticulatus здатний передавати збудники і взимку (Karbowiak, 2009). На основі результатів досліджень інших авторів та наших результатів підтверджено, що цілорічна активність є нормальною поведінкою для D. reticulatus, отже, це відіграє важливу роль у циркуляції трансмісивних хвороб протягом цілого року. Тому в ендемічних регіонах повинен забезпечуватися цілорічний захист тварин від кліщів, особливо пізньої осені, під час м'якої зими та ранньої весни, оскільки активність D. reticulatus у ці періоди може спричиняти захворювання, які переносять кліщі (Levytska \& Berezovskyi, 2019).

Низька кількість ураження кліщами котів, ймовірно, пов'язана з їхньою поведінкою та тим, що у ветеринарні клініки в основному потрапляли домашні тварини (Marchiondo et al., 2013). Більшість кліщів, зібраних від котів, були I. ricinus. Вища ураженість I. ricinus може бути пояснена або відбором господарів (вважається, що дорослий D. reticulatus харчується великими ссавцями), або типом акарициду, яким ко- 
ристуються господарі. Більшість препаратів, що застосовуються для котів в Україні, містять фіпроніл. Ця діюча речовина $є$ недостатньо ефективною щодо європейського лісового кліща, але $\epsilon$ найбільш ефективним акарицидом проти пасовищного кліща D. reticulatus (Beck et al., 2014; Bajer et al., 2014b).

\section{Висновки}

Отже, в західних областях України у природних біоценозах, а також серед сільськогосподарських та домашніх тварин широко поширені два види кліщів: I. ricinus та $D$. reticulatus, домінуючим видом $\epsilon$ D. reticulatus. Даний вид кліщів $є$ активним протягом усього року, тому необхідними є постійні профілактичні обробки тварин - для запобігання зараженню кліщовими захворюваннями.

\section{References}

Bajer, A., Mierzejewska, E.J., Rodo, A., Bednarska, M., Kowalec, M., \& Welc-Fale ciak, R. (2014a). The risk of vector-borne infections in sled dogs associated with existing and new endemic areas in Poland. Part 1: A population study on sled dogs during the racing season. Vet Parasitol, 202(3-4), 276-286. doi: 10.1016/j.vetpar.2013.12.033.

Bajer, A., Mierzejewska, E. J., Rodo, A., Welc-Falęciak, R. (2014b). The risk of vector-borne infections in sled dogs associated with existing and new endemic areas in Poland. Part 2: occurrence and control of babesiosis in a sled dog kennel during a 13-year-long period. Vet Parasitol, 202(3-4), 234-240. doi: 10.1016/j.vetpar.2014.02.007.

Beck, S., Schreiber, C., Schein, E., Krücken, J., Baldermann, C., Pachnicke, S., von Samson-Himmelstjerna, G., \& Kohn, B. (2014). Tick infestation and prophylaxis of dogs in northeastern Germany: a prospective study. Ticks Tick Borne Dis, 5(3), 336-342. doi: 10.1016/j.ttbdis.2013.12.009.

Beklemishev, V. N. (1961). Terms and concepts needed for the quantitative accounting populations ectoparasites and nikodils. Zool. Journal., 40(2), 148-158.

Beugnet, F., \& Chalvet-Monfray, K. (2013). Impact of climate change in the epidemiology of vector-borne diseases in domestic carnivores. Comp Immunol Microbiol Infect Dis, 36(6), 559-566. doi: 10.1016/j.cimid.2013.07.003.

Boulanger, N., Boyer, P., Talagrand-Reboul, E., \& Hansmann, Y. (2019). Ticks and tick-borne diseases. Med Mal Infect, 49(2), 87-97. doi: 10.1016/j.medmal.2019.01.007.

Buczek, A., Bartosik, K., \& Zając, Z. (2014). Changes in the activity of adult stages of Dermacentor reticulatus (Ixodida: Amblyommidae) induced by weather factors in eastern Poland. Parasit Vectors 7, 245. doi: 10.1186/1756-3305-7-245.

Caminade, C., McIntyre, K. M., \& Jones, A. E. (2019). Impact of recent and future climate change on vector- borne diseases. Ann N Y Acad Sci, 1436(1), 157-173. doi: 10.1111/nyas.13950.

Claerebout, E., Losson, B., Cochez, C., Casaert, S., Dalemans, A. C., De Cat, A., Madder, M., Saegerman, C., Heyman, P., \& Lempereur, L. (2013). Ticks and associated pathogens collected from dogs and cats in Belgium. Parasit Vectors, 6, 183. doi: 10.1186/17563305-6-183.

Dautel, H., Dippel, C., Kämmer, D., Werkhausen, A., \& Kahl, O. (2008). Winter activity of Ixodes ricinus in a Berlin forest. Inter J Med Microbiol, 294(1), 50-54. doi: 10.1016/j.ijmm.2008.01.010.

Derzhavna sluzhba statystyky Ukrainy (2019). Rezhym dostupu https://ukrstat.org/uk/operativ/operativ2006/ sg/sg_rik/sg_u/tvar_u.html (in Ukrainian).

Duscher, G. G., Feiler, A., Leschnik, M., \& Joachim, A. (2013). Seasonal and spatial distribution of ixodid tick species feeding on naturally infested dogs from Eastern Austria and the influence of acaricides/ repellents on these parameters. Parasit Vectors, 6, 76. doi: 10.1186/1756-3305-6-76.

Filippova, N. A. (1977). Iksodovi klishchi pidrodyny Ixodinae. Fauna SRSR. Arakhnida. Leninhrad, Vydavnytstvo. Nauka (in Ukrainian).

Földvári, G., \& Farkas, R. (2005). Ixodid tick species attaching to dogs in Hungary. Vet Parasitol, 129(1-2), 125-131. doi: 10.1016/j.vetpar.2004.11.032.

Hamel, D., Silaghi, C., Zapadynska, S., Kudrin, A., \& Pfister, K. (2013). Vector-borne pathogens in ticks and EDTA- blood samples collected from clientowned dogs, Kiev, Ukraine. Ticks Tick Borne Dis, 4(1-2), 152-155. doi: 10.1016/j.ttbdis.2012.08.005.

Iemchuk, Ye. M. (1960). Fauna Ukrainy. Tom 25 [Iksodovi klishchi], Vyp. 1. Zovnishnia i vnutrishnia budova, ekolohiia, systematyka, poshyrennia ta shkidlyvist iksodovykh klishchiv. Kyiv Vydavnytstvo AN Ukrainskoi RSR (in Ukrainian).

Izdebska, J. N. (2001). The occurrence of parasitic arthropods in two groups of European bison in the Białowieza primeval forest. Wiad Parazytol, 47(4), 801-804. https://www.ncbi.nlm.nih.gov/pubmed/16886430.

Karbowiak, G. (2009). Kleszcz ła kowy Dermacentor reticulatus- wyste powanie, biologa i rola jako wektora choro'b odkleszczowych. Habilitation thesis. Instytut Parazytologii im. Witolda Stefan'skiego PAN, Warsaw.

Karbowiak, G. (2014). The occurrence of the Dermacentor reticulatus tick-its expansion to new areas and possible causes. Ann Parasitol, 60(1), 37-47. https://www.ncbi.nlm.nih.gov/pubmed/24930245.

Kilar, P. (2011). Ticks attacking domestic dogs in the area of the Rymanów district, Subcarpathian province, Poland. Wiad Parazytol, 57(3), 189-191. https://www.ncbi.nlm.nih.gov/pubmed/22165742.

Kolonin, G. V. (2006). Fauna of Ixodid Ticks of the World (Acari, Ixodidae). http://web.archive.org/web/ 20100922170628/http://www.kolonin.org/3.html.

Kybicova, K., Bastova, K., \& Maly, M. (2017). Detection of Borrelia burgdorferi sensu lato and Anaplasma phagocytophilum in questing ticks Ixodes ricinus from 
the Czech Republic. Ticks and Tick-borne Diseases, 8(4), 483-487. doi: 10.1016/j.ttbdis.2017.02.007.

Levytska, V. A., \& Berezovskyi, A. V. (2019). Farmakolohichni doslidzhennia eksperymentalnoho preparatu Imkar-120. Visnyk Poltavskoi derzhavnoi ahrarnoi akademii, 2, 119-125. doi: 10.31210/visnyk2019.02.15 (in Ukrainian).

Marchiondo, A. A., Holdsworth, P. A., Fourie, L. J., Rugg, D., Hellmann, K., Snyder, D. E., \& Dryden, M. W. (2013). World Association for the Advancement of Veterinary Parasitology (W.A.A.V.P.) second edition: guidelines for evaluating the efficacy of parasiticides for the treatment, prevention and control of flea and tick infestations on dogs and cats. Vet Parasitol, 194(1), 84-97. doi: 10.1016/j.vetpar.2013.02.003.

Medlock, J. M., Hansford, K. M. et al. (2013). Driving forces for changes in geographical distribution of Ixodes ricinus ticks in Europe. Parasite Vectors, 6, 1. doi: 10.1186/1756-3305-6-1.

Mierzejewska, E. J., Pawełczyk, A., Welc-Fale ،ciak, R., Radkowski, M., \& Bajer, A. (2013). Co-infections involving TBE virus, Babesia and Rickettsia spp. In: Dermacentor reticulatus ticks. XXIII Congress of the Polish Parasitological Society, Szklarska Pore baPiechowice, September 2013, Annals of Parasitology, 59, 182.

Nowak-Chmura, M., \& Siuda, K. (2012). Ticks of Poland: review of contemporary issues and latest research. Ann Parasitol, 58(3), 125-155. https://www.ncbi.nlm.nih.gov/pubmed/23444797.

Ogden, N. H., Cripps, P., Davison, C. C., Owen, G., Parry, J. M., Timms, B. J., \& Forbes, A. B. (2000). The ixodid tick species attaching to domestic dogs and cats in Great Britain and Ireland. Med Vet Entomol, 14(3), 332-338. doi: 10.1046/j.1365-2915.2000.00244.x.
Reye, A., Stegniy, V., Mishaeva, N., \& Velhin, S. (2013). Prevalence of tick-borne pathogens in Ixodes ricinus and Dermacentor reticulatus ticks from different geographical locations in Belarus. PLoS One, 8(1), e54476. doi: 10.1371/journal.pone.0054476.

Roczeń-Karczmarz, M., Dudko P., Demkowska-Kutrzepa M., Meisner M., Studzińska M., Junkuszew A., Sopińska A., \& Tomczuk, K. (2018). Comparison of the occurrence of tick-borne diseases in ticks collected from vegetation and animals in the same area. Medycyna Weterynaryjna, 74, 484-488. doi: 10.21521/mw.6107.

Smith, F. D., Ballantyne, R., Morgan, E. R., \& Wall, R. (2011). Prevalence, distribution and risk associated with tick infestation of dogs in Great Britain. Med Vet Entomol, 25(4), 377-384. doi: 10.1111/j.13652915.2011.00954.x.

Welc-Falęciak, R., Kowalec, M., Karbowiak, G., Bajer, A., Behnke, J. M., \& Siński, E. (2014). Rickettsiaceae and Anaplasmataceae infections in Ixodes ricinus ticks from urban and natural forested areas of Poland. Parasites Vectors, 7, 121. doi: 10.1186\%2F1756-3305-7121.

Zahler, M., \& Gothe, R. (1995). Effect of temperature and humidity on egg hatch, moulting and longevity of larvae and nymphs of Dermacentor reticulatus (Ixodidae). Appl Parasitol, 36(1), 53-65. https://www.ncbi.nlm.nih.gov/pubmed/7780450.

Zygner, W., Górski, P., \& Wedrychowicz, H. (2009). New localities of Dermacentor reticulatus tick (vector of Babesia canis canis) in central and eastern Poland. Pol J Vet Sci, 12(4), 549-555. https://www.ncbi.nlm.nih.gov/pubmed/20169932. 